\title{
Mining Law: In Search of Sustainable Mining
}

\author{
Nathalie Barbosa Reis Monteiro ${ }^{1, * \mathbb{D}}$, Ana Keuly Luz Bezerra ${ }^{2} \mathbb{D}$, José Machado Moita Neto ${ }^{1 \mathbb{D}}$ and \\ Elaine Aparecida da Silva ${ }^{1}$ (D)
}

1 Department of Development and Environment, Ministro Petrônio Portella Campus, Federal University of Piauí, Teresina, Piauí 64049-550, Brazil; jmoita@ufpi.edu.br (J.M.M.N.); elaine@ufpi.edu.br (E.A.d.S.)

2 Department of Law, Dirceu Arcoverde Campus, Federal Institute of Piauí, Teresina, Piauí 64053-120, Brazil; prof.anakeuly@gmail.com

* Correspondence: nathaliereis@hotmail.com; Tel.: +55-(15)-996883194

Citation: Monteiro, N.B.R.; Bezerra, A.K.L.; Moita Neto, J.M.; Silva, E.A.d. Mining Law: In Search of Sustainable Mining. Sustainability 2021, 13, 867. https://doi.org/10.3390/su13020867

Received: 17 November 2020

Accepted: 12 January 2021

Published: 16 January 2021

Publisher's Note: MDPI stays neutral with regard to jurisdictional claims in published maps and institutional affiliations.

Copyright: (c) 2021 by the authors. Licensee MDPI, Basel, Switzerland. This article is an open access article distributed under the terms and conditions of the Creative Commons Attribution (CC BY) license (https:/ / creativecommons.org/licenses/by/ $4.0 /)$.

\begin{abstract}
Mining is an activity that generates inputs to different production chains, making it essential for any country's development. However, it causes environmental, economic, and social impacts that must be considered. The Mining Law provides guidelines, through laws and regulations, so the activity can be carried out in an environmentally, economically, and socially sustainable way. In this paper, an analysis was conducted of the application of some peculiar characteristics of Brazilian Mining Law (locational rigidity, priority granting, among others) according to the parameters established in the Federal Constitution, in the Mining Code and its updates, and in the National Department of Mineral Production, Environment Ministry, and Mines and Energy Ministry normative acts. Moreover, the Superior Court of Justice Jurisprudence was analyzed to understand how the Mining Law is applied, in practice. It was verified that the Brazilian legislation is not perfect, but it has mechanisms to protect and benefit the miner, the society, and the environment. However, there are many shortcomings like the lack of speed in judging processes and the flaws in the applicability of some principles that compromise sustainability in the activity's development, especially regarding the environmental and social liabilities left after mine closure.
\end{abstract}

Keywords: mineral sustainability; environmental legislation; mining law; environmental impacts; social impacts; social justice

\section{Introduction}

Mining generates inputs that are present in several economic sectors: energy production, civil construction, agribusiness, electronics, jewelry, among others, which makes mineral resources strategic for many nations. It is a necessary activity that moves a vast productive chain; however, mining causes several impacts due to the extraction of nonrenewable natural resources. In addition, it has environmental, economic, and social inherent risks [1,2].

Among the environmental risks there are impacts like deforestation of the mined area, contamination of water courses, air and noise pollution, and the depletion of natural resources [3]. Economic risks are linked to high investments, market fluctuations, changes in the commodities price, among others [4]. For society, the risks are mainly related to the effects after the end of the activity and the mine's closure: the community around the mine needs to deal with an environmental and social liability that did not exist before the opening of the industry [5]. Table 1 shows the positive and negative impacts associated with mining activity, in the three spheres (environmental, social, and economic). 
Table 1. Positive and negative impacts caused by mining activity.

\begin{tabular}{|c|c|c|}
\hline Mining Impacts & Positives & Negatives \\
\hline Economic & $\begin{array}{l}\text { Tax collection; } \\
\text { Generation of jobs and income; } \\
\text { Attracting other economic activities to the region; } \\
\text { Use of mineral goods as an income source }\end{array}$ & $\begin{array}{c}\text { High investments; } \\
\text { Market fluctuations } \\
\text { Changes in commodity prices; } \\
\text { Bankruptcies; } \\
\text { Corruption of inspection agencies }\end{array}$ \\
\hline Social & $\begin{array}{l}\text { Improvement in the region's infrastructure; } \\
\text { Promotion of human dignity through employment } \\
\text { and improvement in family income; } \\
\text { Greater purchasing power, promoting income for } \\
\text { other commercial sectors in the region; } \\
\text { Attracting public investments like schools and } \\
\text { hospitals for population; } \\
\text { Use of mineral goods for the benefit of the } \\
\text { population (for example, in the manufacture of } \\
\text { various medical/hospital equipment) }\end{array}$ & $\begin{array}{c}\text { Loss of jobs after mine closure; } \\
\text { Poverty situation after mine closure; } \\
\text { region; } \\
\text { Loss of other industrial/commercial activities in the } \\
\text { Community abandonment; } \\
\text { Negative influence on culture, especially on } \\
\text { indigenous peoples and traditional communities (loss } \\
\text { of cultural identity); } \\
\text { Misuse of mineral goods (for example, manufacture of } \\
\text { objects as weapons for criminal purposes) }\end{array}$ \\
\hline Environmental & $\begin{array}{l}\text { Recovery of degraded areas; } \\
\text { Reforestation; } \\
\text { Reuse of the mine area for other social purposes } \\
\text { (for example parks, concert space, stadiums) }\end{array}$ & $\begin{array}{c}\text { Environmental degradation; } \\
\text { Changes in the landscape, vegetation structure and } \\
\text { ecosystem of the region; } \\
\text { Climate changes; } \\
\text { Noise pollution; } \\
\text { Emission of particulate matter; } \\
\text { Pollution of soil, water, and air; } \\
\text { Deforestation }\end{array}$ \\
\hline
\end{tabular}

Mining Law points out procedures, rules and guidelines that manage the sector, so that mineral exploration may have the least adverse impact on the environment. In addition, it provides regulations regarding the transformation of the mineral resource, resulting in benefits from the economic and social point of view, guaranteeing the rights of the miner, the country, and the society, in favor of economic, environmental, and social sustainable development [6]. Although mining laws exist with the purpose of ensuring the activity's development in a sustainable manner, there are flaws because there is no perfect legislation, as well as the applicability of the law not being perfect.

Mining in Brazil is regulated by the Federal Constitution [7], which establishes the general rules and activity's guiding principles. In addition, there is the Mining Code [8] and its updates, which are the special laws that control the sector. Furthermore, there are specific laws, such as Law 8001 of 1990, which define the percentages of the financial compensation distribution [9]. The normative acts by the National Department of Mineral Production (NDMP), the Ministry of the Environment (ME) and the Ministry of Mines and Energy (MME) regulate the exercise of mining, however, without creating, modifying, or extinguishing rights [10]. More recently, also, the Decree 9406 of 12 June 2018 [11] regulates the Mining Code and other laws of the sector.

Mining Law has a dual nature, being considered a public right in the Federal Government/miner relationship and private in the mining/communities/consumers relationship [6]. Among the general constitutional principles established for mining activity there are: national interest and public utility; the national sovereignty in the use of resources; and the need to consider the social function of mineral property so that there is an effective contribution to society through, mainly, promoting improvements regarding the region's infrastructure where the mines are installed [12].

In fact, mining companies promote benefits related to improvements to the site's infrastructure and promote access to mineral resources that are of public interest. However, does this compensate for the negative impacts generated by the activity? This is a question that must be answered in the light of the sustainability tripod (environmental, economic, and social). To what extent should the economic and social benefits outweigh the environ- 
mental impacts caused by mining? The law seeks to provide for this assessment so that there can be sustainability in the activity.

Among other important principles of Mining Law, there are: intergenerational responsibility, that is, the obligation to preserve the environment for current and future generations; the locational rigidity, which means that it is not possible for the miner to choose the place to be mined because it depends exclusively on the availability of the mineral in nature; maximum and efficient use of resources, avoiding waste and using the full potential of the mine; real estate duality, which declares that the surface and the subsoil belong to the land owner, but the mineral wealth is property of the Federal Government, among others [13].

Brazilian mining law considers all types of mining: on land, submarine and in riverbeds. The present article will analyze mainly mining on land. Thus, in this paper, an analysis was made of the legislation regarding the specific field of Mineral Law. The aim of this study is to reflect on its application for the benefit of the environment and society, besides the economic implications of this application. In addition, the purpose of this study is to verify how the mining companies have dealt with the environmental and social liabilities after the end of exploration and what are the consequences for society, which needs to face this problem.

\section{Materials and Methods}

The existing legislation for the mineral sector covering the Federal Constitution, the Mining Code and its updates, and the normative acts of the NDMP, ME and MME were analyzed. In addition, a survey was carried out on the website of the Supreme Court of Justice (SCJ) in order to learn about the SCJ's jurisprudence related to mining law. The search was made using the term "mining law", which recovered a total of fourteen Judgments and 141 Monocratic Decisions.

A systematic search was also carried out in the scientific literature to find publications related to the application of laws regarding mining activity, comparing Brazilian legislation with others around the world. The search was made on the Coordination of Improvement of Higher Education Personnel (CAPES) Portal, using the keyword "mining law", in the "advanced search" field and with the filters "publication date" (last ten years) and "type of material" (articles). The corpus obtained was made up of 43 articles that deal with the following topics of Mining Law (Table 2).

Systematic review is a type of research which follows specific protocols and seeks to give some logic to a large documentary corpus [14]. In this article, we select some categories identified in the Law regarding sustainability, comparing them to SCJ Jurisprudences and the scientific literature. Table 2 describes the selected categories, the jurisprudence found, and the sources identified in the scientific literature for each category.

In addition to the sustainability categories selected for analysis, issues such as corruption, methods for preparing Environmental Impact Studies (EIA), public policies, among others, were discussed throughout the text, pointing out the flaws in the Law related to sustainability in mining activity. 
Table 2. The categories identified in the Law related to sustainability.

\begin{tabular}{|c|c|c|}
\hline Categories & Jurisprudences & Scientific Literature \\
\hline National sovereignty in the use of resources & $\begin{array}{l}\text { Special Appeal, No. 1,394,171-RS } \\
(2013 / 0266001-0)\end{array}$ & {$[6]$} \\
\hline Real estate duality & $\begin{array}{c}\text { Special Appeal, No. 1,394,171-RS } \\
(2013 / 0266001-0)\end{array}$ & [12] \\
\hline Granting by priority & $\begin{array}{l}\text { Writ of Mandamus, No. 6768/DF } \\
(2000 / 0002376-0)\end{array}$ & {$[4,5]$} \\
\hline Mining easement & $\begin{array}{c}\text { Special Appeal, No. 1,369,723-MG } \\
(2013 / 0048546-5)\end{array}$ & [15] \\
\hline Damage and income assessment & $\begin{array}{c}\text { Special Appeal, No. 1,124,158-MG } \\
(2017 / 0150730-8)\end{array}$ & [6] \\
\hline Recovering degraded areas & $\begin{array}{c}\text { Special Appeal No. 1,374,284-MG } \\
(2012 / 0108265-7)\end{array}$ & [16-21] \\
\hline Relationship between landowners and miner & $\begin{array}{c}\text { Special Appeal, No. 1,205,612-SC } \\
(2017 / 0288229-5) \\
\text { Special Appeal, No. 1,124,158-MG } \\
(2017 / 0150730-8)\end{array}$ & {$[4-6,22]$} \\
\hline Public hearings/society involvement & $\begin{array}{l}\text { Special Appeal No. 1,479,063-RS } \\
(2014 / 0223436-1)\end{array}$ & {$[16,23-25]$} \\
\hline Licensing process & $\begin{array}{l}\text { Special Appeal No. 1,479,063-RS } \\
(2014 / 0223436-1)\end{array}$ & {$[16,26,27]$} \\
\hline Intergenerational responsibility & $\begin{array}{c}\text { Special Appeal No. 1,374,284-MG } \\
(2012 / 0108265-7)\end{array}$ & [16-21] \\
\hline Locational rigidity & $\begin{array}{c}\text { Special Appeal, No. 1,205,612-SC } \\
(2017 / 0288229-5)\end{array}$ & {$[4,5,22]$} \\
\hline Maximum and efficient use of resources/mine's closure & $\begin{array}{c}\text { Special Appeal No. 1,374,284-MG } \\
(2012 / 0108265-7)\end{array}$ & [28-30] \\
\hline
\end{tabular}

\section{Results}

The first step in understanding the application of Mining Law is to define concepts that are confused in this context. There is a difference between mineral substance, mineral resource, and mineral product. Mineral substance is any substance present in the Earth's crust; mineral resource is everything that can be extracted for the manufacture of products; and mineral product is the ore processed and ready to be used. Other terms that also need to be defined are deposit and mine. Not every mineralized body is a deposit and not every deposit is a mine. Deposit is a place on the rocks where the ore is found, it is the mineral reserve with economic value. Mine is the exploration, by man, in the deposit. So, the mine is the deposit economically exploited [13].

The mineral asset is owned by the Federal Government, but the product of exploitation belongs to the owner of the land (or the miner, if they are different entities). Thus, the Federal Government is responsible for legislating on mineral deposits and resources, which authorizes individuals or companies to exploit them according to national interest and sovereignty. Brazilian mining law applies to both land and sea/river mining. Thus, the mineral product belongs to the miner, but not the mineral resource $[6,11]$.

\subsection{The Real Estate Duality}

The principle of real estate duality recognizes that there are two owners of the same land space (the Federal Government and the landowner). The competence to manage the exploitation of mineral resources before Decree 9,406 of 12 June 2018 was from NDMP. After this date it became the National Mining Agency (NMA), and the criteria established for this are: availability of resource, possibility of exploitation, economic and social benefits, among others [11].

The SCJ judged a Special Appeal, No. 1,394,171-RS (2013/0266001-0), in 2018, referring to a company that was exploiting an area without the proper authorization from 
NDMP [31]. The provision was denied, since such an act is considered an environmental crime subject to sanction, according to the legislation. The defendant company claimed the principle of insignificance, provided by Article 2 of Law Decree 227/67 [8], which authorizes the extraction of mineral substances for immediate application in public works. However, it was proven that the company commercialized the extracted product, thus committing environmental crime. Therefore, the exploitation of natural resources, without authorization from NDMP, or NMA, is considered a crime.

The exploration authorization granted by the competent agency minimizes negative impacts as it implies that environmental studies have been carried out in the area. Usually, the procedure takes time due to the high volume of processes and the bureaucracy [4]. In some cases, the delay may even lead to cases of corruption and bribery of environmental agents for issuing authorization [32]. However, compliance with the law helps to reduce cases of exploitation without proper authorization, promoting protection for the environment and society.

\subsection{The Mineral Research Permit}

To guarantee the activity's social contribution (public interest), it is necessary to consider the rules for the use of mineral resources. One of them is mineral research, which is the execution of works that will define the region's potential for exploration and includes activities that aim at identifying viable mineralized bodies from the economic point of view. The requirements for it are: detailed geological surveys of the researched area; outcrop studies; geophysical and geochemical surveys; opening excavations to analyze the mineral body; systematic sampling; physical and chemical analyzes of the samples; and processing of ores or useful mineral substances to obtain products according to market specifications or industrial use [33].

For that, it is necessary to apply for the mineral research permit, which is granted only in free areas and assuming a series of obligations, under penalty of sanctions that vary from a warning to the loss of the exploration right. The approval of the permit guarantees the owner rights such as to access the project area via friendly agreement or legal action and the possibility of requesting mining within one year. However, the filing of a negative report makes the area free for new requirements [33]. It is important to keep in mind that the social contribution of the activity cannot prevail over the environmental interest. In order to have sustainability in all its aspects, environmental impacts must be considered, together with the public interest in the mineral good.

The mining ordinance holder is responsible not only for opening and operating the mine, but also for closing it. That is the reason it is important to foresee, in business strategies and cash flow, the value of the operations necessary to offset and reverse, when possible, the negative environmental impacts, since the miner must return the exploited area under conditions of use for society [34]. Thus, it is necessary to perform the activity in an environmentally responsible manner, so that the exploration does not result in an unsuitable area for use after the mineral resource depletion. It is certain that mineral replacement is impossible. Once the resource is removed from nature it cannot be "replanted" like vegetal resources, for example. That is why it is important to make environmental compensation for the irreversible damage caused by mining.

There was a case in which the NDMP suspended the license of a company that did not start mineral research within three years, as established in the Mining Code [8]. The company filed a Writ of Mandamus, No. 6768/DF (2000/0002376-0) [35], claiming the impossibility of accessing the area, as it was awaiting judicial authorization to do so. Safety was granted, since the term of the research permits must start from the effective entry into the area that will be explored.

\subsection{The Granting System}

Regarding the granting system, the basic rules for the use of mineral resources are research authorization, license registration, mining permit and extraction registration. In 
addition, there is a system called "Granting by Priority" which, in Mining Law, means that the Federal Government is obliged to consent the exploitation for the person/industry who first regularly request it. The priority system guarantees to the first applicant the right to explore a free area, that is, where there is no previous application [33].

Kai and partners, referring to the Granting by Priority system, highlights conflicts involving mining in indigenous areas or in areas that should be under environmental protection [5]. Many free areas are located, for example, where there are remnants of the Atlantic Forest, which must be conserved because it is an intensely explored biome in Brazil. Gonçalves, Milanez and Wanderley complement the concern with the agrarian space, especially regarding the expansion of mining in rural communities [4].

There are also human rights issues related to the invasion of mining companies, as authorized by the government, in Brazilian indigenous communities in the Amazon. The extinction of the mineral reserve in the Amazon causes strong resistance from society, environmentalists, politicians, and famous figures nationally and internationally [4]. The problem is that this situation opens the door for mining companies and their socioenvironmental impacts and other processes that destroy the environment and the people that live in this territory.

The fact that there is no mining requirement in a specific space does not necessarily make the area free. There are protected areas such as Permanent Protection Areas (PPAs) where it is not possible to mine. There also areas that are not classified as protected, but should be, so the requirement for a free area must be carefully analyzed, by means of an environmental study, so that the Granting of Priority system is not compromised.

\subsection{The Relationship between Landowner and Miner}

The legal basis for the relationship between landowners and miner, when they are not the same person, is established in the Mining Code, Article 27 [8]. The indemnity that must be paid to the landowner must be equivalent to the damage or impact caused, so that the property rights and the exploitation rights of mineral resources can coexist in the same place. The miner is authorized to intervene in the area, and cannot use it for any other purpose, only for the essential works for the mineral research conclusion, thus paying the due value for its use to the owner [36].

There are cases in which the contractual obligations are not fulfilled by one of the parties (landowner or miner), resulting in losses and legal actions. An example is the case of a Special Appeal, No. 1,205,612-SC (2017/0288229-5) [37]. The SCJ upheld the request to determine that the mining company would render accounts and pay the lease due to the landowner once he has the right to share the mining result since he has demonstrated the condition of owner.

Another case was an Embargo of Declaration in the Special Appeal, No. 1,124,158-MG (2017/0150730-8) [38], judged by the SCJ, in 2018. In this case, company X applied for, and obtained, the mining concession to explore an area belonging to another mining company (company $\mathrm{Y}$ ) but did not fulfill the assumed obligation to lease that mining right to the company $\mathrm{Y}$. The company $\mathrm{X}$ was fined and compelled to comply with the contractual obligations assumed by the parties. Thus, the legislation provides that the landowner will not be harmed due to the miner's actions.

In both cases, the concern was about land ownership and exploration rights. However, to achieve sustainability in mining activities, concerns must go beyond the exploration rights. Attention should be paid to the impacts that mining will cause in the area and how to mitigate them. The landowner and the miner must be able to rehabilitate the devastated environment or prevent overexploitation as part of their social responsibility. Therefore, the law fails to only consider the issue of belonging regarding exploitation rights. The wording of the law should also address the ability of the landowner, or the miner, to develop the activity in a sustainable manner. 


\subsection{The Damage and Income Assessment}

Besides the indemnity for the damage caused to the property, the beneficiary (landowner) is entitled to the income he fails to earn due to research. For this, there is a judicial process for Damage and Income Assessment, which is a procedure of voluntary jurisdiction. Voluntary jurisdiction is the attribution of a judicial and non-jurisdictional act, affected by the complex of acts performed by the judge, exercising power, and fulfilling the function that the law is responsible for [39]. Thus, to avoid any loss or damage due to mineral research, it is necessary to prepare an Economic Use Plan (EUP), which contains the mining schedule and information on the expected cash flow for the operation [6]. The mining ordinance application and the processes involved in authorizing ore exploration are guided by the EUP. The miner must respect the guidelines established in the EUP, as well as annually issue a Annual Mining Report (AMR) to monitor and control the exploration, so that there is environmental compensation in the explored area [34].

The mining must start within six months of the EUP approval and continues until the exhaustion of mineral resources, provided that the miner (the holder) complies with all legal requirements for exploration. The mining ordinance has economic value and can be waived, sold, or leased according to the interest of the holder. However, these procedures require the consent of the responsible agency to take effect [33]. Once again, the law is concerned with the economic damage suffered by the landowner. There is no mention of environmental damage, which should be considered for the area to return to society in conditions of use, after exploration.

\subsection{The Principle of Locational Rigidity}

One of the particularities of mining is the impossibility of choosing the location to be mined due to the occurrence of the mineral in the environment. Thus, to resolve the conflict between mining and other public interest activities, such as agribusiness [4,22], it is necessary to apply the principle of locational rigidity, which provides for mining preference over other industrial activities, due to availability of the mineral in nature [8]. However, does this principle consider the impacts caused by mining or agribusiness? The law only considers the availability of the mineral in the environment, disregarding other factors such as environmental impacts, traditional or indigenous populations living in the area, among other factors that should be considered when deciding on mining in a certain area with available ores.

In other parts of the world, this principle can be applied differently. In the USA, in the state of Michigan, the use of land in mining operations is not preferable. The decision on this issue is an exclusively legislative function, which can be taken by the Municipal Government of the affected area [1]. Nothing prevents that, in Brazil, in the future, this will not be applied. Despite the locational rigidity, a municipality can invoke local interest in not having mineral activity, as it would jeopardize other economic activity in the region, for instance, tourism, fishing, etc.

Normally, the presence of mining activity leads people to form villages around industries due to the availability of jobs and prospects for improving infrastructure in the region [36], causing a redistribution of the population in mining regions [40]. In fact, mining companies promote improvements such as paving the roads to access the villages, among others [26]. However, when the mining activity is no longer economically viable, incurring the closure of the mine, there is a real risk of becoming an environmental liability that society will need to bear. Thus, there is a possibility that the area will become even poorer than before the exploration began. In Bogotá, a study showed that the environmental liabilities left by mining areas cause changes in the physical and biotic aspects of the region, changing the ecosystem and the local geomorphology [30]. This reflects on the population's life quality once they are directly affected by these changes. 


\subsection{The Principle of Intergenerational Responsibility}

In the Brazilian Northeast region, the impact related to abandoned mines stands out, due to the depletion of resources and the lack of money to continue investing in exploration. The main consequence of this situation is the toxic waste exposed in the environment. In the Piauí state, Brazil, there is also the occurrence of clandestine mines, derived from the deficiency in inspection, resulting in the accumulation of tailings from illegal extraction, causing various socioenvironmental impacts [41]. Therefore, it is important to assess the mine's lifetime, that is, the time that it will be active to find employment solutions and worthy conditions of subsistence for the populations that come to these regions attracted by the activity. The government needs to create public policies to relocate these people who, possibly, will lose their job and source of income when exploitation ceases.

In this context, the principle of intergenerational responsibility is involved, which presupposes the obligation to conserve the environment for current and future generations [13]. To ensure the compliance with this principle, there is environmental and mineral licensing, which aims to regulate the activity, evaluate the economic and social benefit for the affected region, implement mitigation and environmental compensation measures, since licenses are issued only through the prior study of the region and the feasibility of implementing the enterprise [42].

\subsection{The Environmental Licensing}

Law 6,938, of 31 August 1981, establishes the environmental licensing process as an instrument of the National Environment Policy, necessary for activities with a potential risk of environmental degradation, such as mining [43]. It is characterized by being a procedure composed of three administrative acts: preliminary license, installation license and operation license. The environmental license can be issued by a Municipal, State, or Federal environmental agency, depending on some factors, such as the size of the project and its location. The conflict of competences of the federated entities for licensing issue was defined in complementary law No. 140, of 8 December 2011 [13].

In addition to the environmental license, a mineral license is required for the mining activity, composed of the following phases: (1) concession, in which the research for the beginning of mineral exploration is carried out; (2) licensing, when the license application and registration is granted; and (3) permission, in which the mining permit is issued for the start of exploration. The environmental agencies responsible for issuing licenses (environmental and mineral) must carry out periodic inspections in order to monitor the evolution of the exploration and ensure that it is within the parameters established in the licensing process [42].

In terms of sustainability and environmental protection, the most essential part of the mining law is the Environmental Impact Assessment (EIA). The creation of the National Environmental Policy of Act (NEPA), in the USA, established the first EIA guidelines, that have been given legal and institutional strength in other parts of the world and can be adapted to different contexts and circumstances. The EIA methods assist in analyzing the effectiveness of Environmental Impact Studies (EIS) to evaluate the quality of the study and the information needed for the feasibility of the project [16]. Thus, it is questioned whether these instruments of environmental control are useful in restraining the environmental damages caused by mining.

The environmental and mineral licensing processes are carried out by presenting the environmental study on the affected region. In these studies, there are surveys about the environmental impacts, as well as the activity's social contributions [44]. Among the social functions of the activity, there is the generation of jobs, the increase in public collection through taxes, the provision of resources for production chains, improvement in local infrastructure, with the construction of roads, basic sanitation works, among others [16,26].

Thus, is it possible to reconcile mining and sustainable development, through compensatory practices? The Brazilian Institute of the Environment and Renewable Natural Resources (IBAMA) report states that compensatory measures are one of the alternatives 
to promote the least aggression to nature and environmentally and socially responsible attitudes, such as the replacement of vegetation in a degraded place nearby the project, when it is not possible to recover the place where the exploration is happening [34].

However, these forms of compensatory practices can ignore the fact that the damage can be irreversible and that this can cause cumulative (social or environmental) degradation. The replacement vegetation on nearby areas, or biodiversity and habitat offsets, is an imperfect practice. It is possible to restore some ecosystem service function, but there will still be cumulative and permanent losses in genetic diversity. Some aspects of biodiversity cannot be restored, therefore, there will invariably be a loss of potential biodiversity assets for future generations. Even with social compensation, for instance, monetary compensation for compulsory land acquisition, this still causes social displacement, despite the monetary benefits for the recipients. Therefore, the effectiveness of compensation processes can be highly variable, and the form of compensation can generate new impacts. So, determining the equivalence of compensation has many theoretical and conceptual challenges.

Furthermore, the licensing process, even if it is not properly executed, should predict, and prevent environmental accidents such as that which occurred in the rupture of the tailings dam in Mariana, Minas Gerais, Brazil [27]. In the case of this accident, the licensing and regulatory process failed. For this, it is also important to perform periodic inspections by the environmental agency. A licensing process should, at the very least, be rigorous enough that, even when performed incorrectly, it still protects local environments and lives.

\subsection{The Obligation of Environmental Recovery}

The Brazilian justice system has enforced compliance with this obligation in cases of environmental accidents, even though, many times, the processes take years to complete. In 2014, the SCJ judged a Special Appeal No. 1,374,284-MG (2012/0108265-7) [45], in which a mining company appealed the penalty of environmental recovery and indemnities payment for the damages resulting from the rupture of the dam waste. It happened in 2007, when two billion liters of toxic sludge leaked, spreading through the states of Minas Gerais and Rio de Janeiro, leaving several families homeless. The SCJ denied the appeal, stating that it is unreasonable to invoke, for the company responsible for environmental damage, exclusions from civil liability to remove their obligation to indemnify, since "the liability for environmental damage is objective, informed by the integral risk theory, being the causality nexus the linking factor that allows the integration of the risk into the unity of the act" [34] (p. 1).

However, there is a failure to comply with the obligation of environmental recovery in the mining company's daily routine. In a study carried out in Minas Gerais, Brazil, it was found that many mining companies fail to comply with the requirements of licensing and environmental standards, operating without the concern of preserving native vegetation remnants or recovering degraded areas [17]. Another study on crushed stone industries, located in the Brazilian Northeast region, showed that the areas are not recovered while being explored and there is no concern to recover areas neighboring the projects. Moreover, there are no periodic inspections by the responsible environmental agency [16]. In São Paulo state, Brazil, it was found that mining companies were not implementing the mitigation actions provided for the environmental studies, compromising the recovery of degraded areas [18]. Thus, the elaboration of a good environmental study is a necessary, but not sufficient, condition to guarantee that the mitigating measures are fulfilled by the industries. Some mitigating measures are listed only as a proposal and, unfortunately, they are no longer effectively implemented.

Therefore, there is a failure in the applicability of Brazilian mineral legislation regarding the recovery of degraded areas; the study developed by Goh and Effendi [19] points out the importance of continuously reviewing the national mineral policy, so that environmental and social sustainability measures, such as the recovery of degraded areas, are successful in their application. Baumbach, Prado Filho, and Fonseca found that mining companies deal with environmental challenges, predominantly, in a reactive manner, rather than 
anticipating them, preventing problems, and seeking effective mitigation solutions [20]. Companies, when opting for insufficient environmental recovery, practice enrichment without cause, as the costs of an adequate environmental recovery were already foreseen.

Other parts of the world face similar situations. In Papua New Guinea, the exploitation of mineral wealth is not translated into development for the country, as evidenced by social indicators performance. The revenue from the exploitation of natural resources does not reflect improvements in the provision of essential services to the population, such as infrastructure and employment, as well as the recovery of degraded areas, leaving the economic return only in the hands of the mining companies' owners [21]. There are also cases of corruption [32] by environmental agents who accept bribes for not applying the fines due for exploitation not compatible with the provisions of the environmental license, which seriously compromises sustainability in the activity, consequently causing damage to the environment and society.

One of the obstacles, in Brazil, to complying with the obligation regarding the environmental recovery is the low price of products in the domestic market for some mineral inputs, once the cost of environmental recovery is treated, in practice, as a negative externality ("environmental dumping"), reducing the price of the product, but maintaining the profitability of the business due to the sales volume. This is common for some construction aggregates [16]. These data are relevant since the area must be returned to society in conditions to be used, involving costs with its recovery, which need to be accounted for. The lack of economic resources should not be an obstacle when recovering the degraded environment. Similar situations also happen in other countries, such as: Spain, Ireland, United States, Canada [46,47]. Beyond that, the lack of speed in judging processes may encourage mining companies to act without concern for environmental risks.

\subsection{The Mining Easement}

Another particularity of mining is that the areas necessary for the installation of mining projects can (and should) be subject to mining easement, which is linked to the mining ordinance. The easement can reach real estate and mining rights, even outside the titled polygonal. It means that not only will the exact location of the mine be subject to the mineral easement, but also the transport routes, workshops, housing, among other enterprises, which can be in a friendly or judicial way. In the polygonal of the ore deposit, the mining title itself is sufficient for purposes of mining easement. In the mine's accessory structures, the easement will depend on delimitation by the NMA, after analyzing the miner's requirement and, if there is any loss, the injured party is entitled to compensation [13].

In 2013, the SCJ dismissed a Special Appeal, No. 1,369,723-MG (2013/0048546-5) [48], in which the mining company had been granted the possession of the easement through the deposit in judgment of the full value of the assessment. The landowner was indemnified for the easement and, therefore, was not entitled to request a new analysis of the judgment, since a new fact was not configured.

Mineral easements are essential areas for the development of a mineral enterprise and their applicability is governed by the Mining Code. In all phases of a mining enterprise and for different purposes, the use of adjacent areas can contribute to the industry's social objective, generating conditions for sustainable regional development [15]. Many benefits can come from the involvement of society, through easement. In addition to the existing companies at the site, others tend to be set up, attracted by the trade. The problem with this situation is that, many times, there is high investment in the installation of these establishments without consideration that the mining company activity has a determined time, due to the depletion of mineral resources. Prior to the cessation of exploration and the closure of the mine, it is necessary to seek an alternative for these establishments that will lose their main buyers.

Situations like this can trigger bankruptcy proceedings, since there is no longer a consumer for specific products, creating social problems that did not exist before the operation of the mines. In addition, there is the environmental liability left by these 
industries that often do not recover the degraded environment [30]. To minimize these situations, it is necessary to involve all actors (industry, government, and society) with the purpose of enforcing compliance with legal measures related to troubles after the end of exploration. This means that public policies must be created in order to solve the social problems that arise from the mines closure.

In Chile, the governance model in which the State promotes private interests, has generated uneven economic development and environmental degradation regarding mining activity. The diminished regulatory capacity and the lack of monitoring environmental practice have social and environmental consequences of degradation, which are often irreversible [28]. The main legal acts that regulate mineral policy in 21 European Union countries prescribe the conservation of geological heritage as an economic resource, promoting its rational use. Dialogue between various stakeholders, including representatives from industry, government, and society, allows balance in the needs of mining areas' conservation [29].

\subsection{The Public Hearing as an Instrument to Promote Sustainability}

One way to make society's involvement result in the feasibility of solutions for environmental and social liabilities is through public hearings. Brazilian law requires that extractive enterprises have their licensing request communicated to society, through local media, such as newspapers, so that public hearings may be required, which are promoted by the environmental agency or may be requested by a civil entity, by the Public Ministry, or by fifty or more citizens [49].

This instrument guarantees to society the provision of clarifications regarding the undertakings and the possibility of discussing solutions for the region after the mine closure. In Peru, involvement through public hearings is so significant that it has led the government to review mining projects, resulting in suspension or cancellation, in some cases [24]. On the contrary, in crushed stone mines (like basalt used in construction) located in the Brazilian Northeast, there is an evidence that there are no public hearings, compromising the involvement of communities in the licensing and installation process [16]. People need to know their right to participate in public hearings and this is done through media, newspapers, television, etc. Access to information enables popular participation and the involvement of society, with transparency. This helps to promote sustainability in the sector.

The lack of clarification regarding the activity can generate a series of local conflicts [23]. A study performed in Ecuador on the conflicts associated with mining operations showed that the population fears the possible social and environmental impact in the long run. Therefore, it is necessary to be aware of people's perceptions since environmental problems can lead to different forms of conflict according to the economic and socio-cultural context of the affected location [25]. It is necessary to inform the population about the risks and benefits of the activity and the public hearing, in this case, becomes the link between the miner and the community.

Misinformation can also generate other types of problems, such as undue denunciations by society. In a Special Appeal No. 1,479,063-RS (2014/0223436-1) [50], judged by the SCJ, in 2017, the request for indemnity of a company that suffered an insincere complaint was granted. The industry was accused of clandestine mining practice. The incident became public, resulting in the interruption of activities and the cessation of profits, due to the initiation of administrative proceedings with NDMP. Consequently, the industry's credibility was undermined, configuring the right to compensation for moral damages [50]. Thus, clarification to society about the activity can avoid situations that may incur losses that would not exist if there was adequate information.

\subsection{The Education as an Instrument to Promote Sustainability}

One way to disseminate sustainability in mining in all its dimensions (social, economic, and environmental) is through education. This is also a potential way to promote the enforcement of mining law, effectively. Environmental education at all levels of teaching, including 
community education, is one of the principles of the National Environment Policy [44], which can contribute to the adoption of sustainable practices in mining activities. There is a limited knowledge about the processes that manage natural resources because scientific disciplines use different concepts and languages to describe and explain complex ecological systems [51].

Thus, sustainability in mining requires a more integrated and interdisciplinary approach that considers the relationships among resources, people, and the environment. The focus on broader systems can contribute to the development of more effective solutions for the management of economic and social environmental problems associated with mining. The effectiveness of the application of Mining Law principles depends on the integration between industry, government, and society, mainly regarding the knowledge of the obligations and rights inherent to the miner and the social responsibility in developing activities within the standards established by law. Table 3 shows the impacts associated with the analyzed jurisprudence and provides a critical analysis of each situation.

Table 3. Critical analysis of each jurisprudence, as well as the impacts associated with them.

\begin{tabular}{|c|c|c|c|}
\hline Jurisprudence & Short Description & Associated Impacts & Critical Analysis \\
\hline $\begin{array}{l}\text { Special Appeal, No. 1,394,171-RS } \\
(2013 / 0266001-0)\end{array}$ & $\begin{array}{c}\text { Mineral exploration } \\
\text { without legal authorization } \\
\text { issued by the National } \\
\text { Department of Mineral } \\
\text { Production (NDMP) }\end{array}$ & $\begin{array}{l}\text { Environmental degradation; } \\
\text { misuse of resources; } \\
\text { illicit enrichment }\end{array}$ & $\begin{array}{c}\text { Authorization is not a mere bureaucracy. } \\
\text { It is protection for the miner and for } \\
\text { society. Illegal and unchecked activity is } \\
\text { detrimental to society, nature, and the } \\
\text { state. }\end{array}$ \\
\hline $\begin{array}{l}\text { Writ of Mandamus, No. 6768/DF } \\
\qquad(2000 / 0002376-0)\end{array}$ & $\begin{array}{l}\text { Mineral research not started } \\
\text { within the period } \\
\text { established in the Mining } \\
\text { Code (three years) }\end{array}$ & $\begin{array}{l}\text { Conflicts with the population; } \\
\text { frustration of job and } \\
\text { income expectations; } \\
\text { early/unnecessary deforestation }\end{array}$ & $\begin{array}{l}\text { The mineral enterprise is complex and } \\
\text { requires planning. It is not a mere } \\
\text { economic position that is established. It } \\
\text { is part of the company's social and } \\
\text { environmental commitment }\end{array}$ \\
\hline $\begin{array}{c}\text { Special Appeal, No. 1,369,723-MG } \\
(2013 / 0048546-5)\end{array}$ & $\begin{array}{l}\text { Compensation for } \\
\text { mining easement }\end{array}$ & $\begin{array}{l}\text { Feasibility of mining activity; } \\
\text { intervention in third party } \\
\text { properties; population discontent; } \\
\text { enrichment of the landowner by } \\
\text { means of indemnities; } \\
\text { environmental degradation }\end{array}$ & $\begin{array}{l}\text { The legislation aims at the rational } \\
\text { exploitation of the resource, the } \\
\text { equalization of interests and protection } \\
\text { of the environment and society. }\end{array}$ \\
\hline $\begin{array}{c}\text { Special Appeal, No. 1,124,158-MG } \\
(2017 / 0150730-8) \\
\text { Special Appeal, No. 1,205,612-SC } \\
(2017 / 0288229-5)\end{array}$ & $\begin{array}{l}\text { Noncompliance with the } \\
\text { obligations between the } \\
\text { miner and the landowner }\end{array}$ & $\begin{array}{l}\text { Environmental degradation; } \\
\text { conflicts between the miner and } \\
\text { the landowner; economic losses } \\
\text { resulting from these conflicts; } \\
\text { disappointment for both parties }\end{array}$ & $\begin{array}{l}\text { Social peace is one of the purposes of } \\
\text { the law. The mediation and arbitration } \\
\text { of conflicts avoids the judicialization of } \\
\text { issues that bring losses to the miner, } \\
\text { landowner and, mainly, to society. }\end{array}$ \\
\hline $\begin{array}{l}\text { Special Appeal No. 1,374,284-MG } \\
(2012 / 0108265-7)\end{array}$ & $\begin{array}{c}\text { Lack of recovering } \\
\text { degraded areas and } \\
\text { environmental accidents }\end{array}$ & $\begin{array}{c}\text { Environmental degradation; } \\
\text { impossibility of recovering the } \\
\text { area after environmental } \\
\text { accidents; ecosystems' lethality; } \\
\text { loss of human lives; poverty; } \\
\text { social maladjustment; serious } \\
\text { material losses }\end{array}$ & $\begin{array}{l}\text { It is not enough to have a vigorous } \\
\text { environmental legislation. It is necessary } \\
\text { for the Executive Branch to be agile in } \\
\text { complying with it so that there is no } \\
\text { judicial breach of basic standards of } \\
\text { good management in mining }\end{array}$ \\
\hline $\begin{array}{l}\text { Special Appeal No. 1,479,063-RS } \\
(2014 / 0223436-1)\end{array}$ & $\begin{array}{l}\text { Unsubstantiated } \\
\text { denunciation about } \\
\text { clandestine mines }\end{array}$ & $\begin{array}{l}\text { Conflicts with the community; } \\
\text { moral damage to the miner; social } \\
\text { deterioration }\end{array}$ & $\begin{array}{l}\text { The population is unaware of the legal } \\
\text { paths for mining and its various stages. }\end{array}$ \\
\hline
\end{tabular}

Brazilian legislation is not perfect. However, it has laws that protect the miner, so that he can perform the exploration in order to obtain the expected profit; protect society, as it establishes the social duties and obligations of the enterprise; and protect the environment because it determines the limits regarding the exploitation of resources, as well as the obligations regarding the recovery of the explored area. In addition, the Judiciary System is slow to judge the processes that have been going on for years, impairing the resolution of environmental and social problems, also impacting economically on the activity's development.

There are several opportunities for improving Brazilian legislation that must be effective to achieve its purpose, while enabling regulatory systems and judicial decisions associated with it in an efficient, equitable, transparent, and effective manner. If decisionmaking processes and responses through the Judiciary take too long to solve problems, 
legislation and regulatory systems should facilitate more proactive risk management and realization of business opportunities in a safe and equitable manner.

Another problem is that environmental agencies are not efficient in carrying out inspections and promoting public hearings, compromising the applicability of the rules established by law. Therefore, it is understood that the problem in Brazil is not only the wording of the law, but also its applicability, which ends up triggering mineral exploration processes outside the parameters, generating economic, social, and environmental unsustainability, in many cases. The applicability of the law does not simply mean the ability to enforce the law, which is partly dictated by the wording of the law, regardless of corruption or incompetence in enforcing agencies. Applicability goes beyond compliance with the law. This depends on the involvement of society and industries, fulfilling their role in doing what the law dictates and the government fulfilling its regulatory and supervisory role.

\section{Conclusions}

Mining is an economic activity with strong locational limitations as it depends on the availability of the mineral in nature. It is of public and national interest and, therefore, in Brazil, its installation is preferred over other activities, due to location rigidity. The dependence of modern society on the mineral goods makes mining essential since the activity provides inputs for several productive chains.

The 1988 Federal Constitution [7] is the basis for the study of Brazilian Mining Law, followed by the Mining Code and the Normative Acts of NDMP, ME and MME. Among the various points, the ownership of mineral goods, which belongs to the Federal Government, and the strategic importance of minerals for economic and social development, linked to environmental protection, stand out.

There are situations in which Mining Law is not effectively applied, such as in the recovery of degraded areas, compromising the effectiveness of the intergenerational principle. This flaw is evident once society needs to deal with the environmental and social liabilities that did not exist before the installation of the project and in cases judged by the SCJ, for instance, the rupture of the tailings dam, which caused environmental/social/economic damages in Minas Gerais, Brazil, in 2007.

Laws, rules, and regulations, if applied correctly, protect the miner, society, and the environment. Although Brazilian legislation covers all these aspects and has mechanisms for mining activities to be performed within the parameters that guarantee the enterprise's sustainability, ensuring the best use of resources and environmental protection, it is not perfect and has plenty of shortcomings that could be improved. Not all problems come from the regulatory and judicial part of the system; however, the failure to apply the laws, to involve society, and the lack of inspections by environmental agencies, in addition to the lack of speed in judging processes, compromises the development of mining in all its potential to be an environmental, social and economic sustainable activity.

Author Contributions: Writing-original draft, N.B.R.M.; writing-review and editing, N.B.R.M., A.K.L.B., J.M.M.N. and E.A.d.S. All authors have read and agreed to the published version of the manuscript.

Funding: This research was funded by CNPq, grant number 401320/2016-2 and 422087/2018-1. The author José Machado Moita Neto thanks CNPq for funding under the Research Productivity Grant, grant number 307215/2015-6".

Institutional Review Board Statement: Not applicable.

Informed Consent Statement: Not applicable.

Data Availability Statement: Data available in a publicly accessible repository that does not issue DOIs. Publicly available datasets were analyzed in this study. This data can be found here: https://www.stj.jus.br/sites/portalp/Jurisprudencia.

Conflicts of Interest: The authors declare no conflict of interest. 


\section{References}

1. Malone, B.D. Mining no longer a preferred land use in Michigan. Nat. Resour. Environ. 2011, 26, 1-4.

2. Monteiro, N.B.R.; Moita Neto, J.M.; da Silva, E.A. Bibliometric study of the crushed stone mining sector. Miner. Process. Extr. Metall. Rev. 2018, 34, 235-249. [CrossRef]

3. Tabatabaei, J.; Mohammadi, F. Environmental Effects of Mining Industries in Meymeh Region, North West of Isfahan. Apcbee Procedia 2013, 5, 388-393. [CrossRef]

4. de Gonçalves, R.J.A.F.; Milanez, B.; Wanderley, L.J. Neoextrativismo Liberal-Conservador: A Política Mineral e a Questão Agrária no Governo Temer. Geogr. Debate 2018, 12, 348-395. [CrossRef]

5. Kai, K.; Buanes, A.; Timo, K.; Masloboev, V.; Pettersson, M. Sustainable mining, local communities and environmental regulation. Barents Stud. Peoples Econ. Politics 2015, 2, 50-81.

6. Ataíde, P. Direito Minerário; Editora Jus Podivm: Salvador, Brasil, 2017; p. 272.

7. Brasil. Constituição da República Federativa do Brasil; Senado Federal: Brasília, Brasil, 1988; p. 292.

8. Brasil. Decreto-Lei No 227, de 28 de Fevereiro de 1967. Dá Nova Redação ao Decreto-lei No 1.985, de 29 de Janeiro de 1940 (Código de Minas). 1967; Brasília. Available online: http:/ / www.planalto.gov.br/ccivil_03/Decreto-Lei/Del0227.htm (accessed on 19 October 2020).

9. Brasil. Lei No 8.001de 13 De Março De 1990. Define os Percentuais da Distribuição da Compensação Financeira de Que Trata a Lei No 7.990, de 28 de Dezembro de 1989, e dá Outras Providências. 1990; Brasília. Available online: http:/ / www.planalto.gov. br/ccivil_03/LEIS/L8001.HTM (accessed on 28 October 2020).

10. Brasil Ministério de Minas e Energia (MME.). Marco Regulatório da Mineração. 2013. Available online: http:/ / www.mme.gov. $\mathrm{br} / \mathrm{web} /$ guest/introducao (accessed on 30 June 2020).

11. Brasil. Decreto No 9.406, de 12 de junho de 2018. Regulamenta o Decreto-Lei No 227, de 28 de fevereiro de 1967, a Lei No 6.567, de 24 de setembro de 1978, a Lei No 7.805, de 18 de julho de 1989, e a Lei No 13.575, de 26 de dezembro de 2017. 2018; Brasília. Available online: http:/ / www2.camara.leg.br/legin/fed/decret/2018/decreto-9406-12-junho-2018-786851-publicacaooriginal155831-pe.html (accessed on 1 November 2020).

12. Feigelson, B. Curso de Direito Minerário, 3rd ed.; Saraiva: São Paulo, Brasil, 2018; p. 368.

13. Brasil. Código de Mineração e legislação correlata; Senado Federal: Brasília, Brasil, 2011; p. 112.

14. Galvão, M.C.B.; Ricarte, I.L.M. Revisão sistemática da literatura: Conceituação, produção e publicação. LOGEION Filos. Inf. 2020, 6, 57-73. [CrossRef]

15. Fernandes, A.G.; Hollanda, H. As servidões minerais e sua natureza jurídica. Rev. Jurídica Uniaraxá 2009, 13, 35-52.

16. Monteiro, N.B.R.; da Silva, E.A. Environmental licensing in Brazilian's crushed stone industries. Environ. Impact Assess. Rev. 2018, 71, 49-59. [CrossRef]

17. Viana, M.B.; Bursztyn, M.A.A. Regularização ambiental nas minerações em Minas Gerais. Rev. Esc. De Minas 2010, 63, 363-369. [CrossRef]

18. Mechi, A.; Sanches, D.L. Impactos ambientais da mineração no estado de São Paulo. Estud. Avançados 2010, 24, 209-220. [CrossRef]

19. Goh, E.; Effendi, S. Overview of an effective governance policy for mineral resource sustainability in Malaysia. Resour. Policy 2017, 52, 1-6. [CrossRef]

20. Baumbach, M.O.; Prado Filho, J.F.; Fonseca, A. Environmental management in small mining enterprises: Comparative analysis of three Brazilian cases through the lenses of ISO 14001. Rev. Esc. Minas 2013, 66, 111-116. [CrossRef]

21. Polume-Kiele, $\mathrm{H}$. The governance of natural resources: Issues affecting better management of revenues and distribution of benefits within Papua New Guinea. Int. J. Rural Law Policy. Spec. Ed. 2014, 1, 1-7. [CrossRef]

22. Gaviria, E.M.A. A "licença social para operar" na indústria da mineração: Uma aproximação a suas apropriações e sentidos. Rev. Bras. Em Estud. Urbanos E Reg. 2015, 17, 138-154. [CrossRef]

23. Zhouri, A.; Oliveira, R. Development and environmental conflicts in Brazil. Challenges for anthropology and anthropologists. Vibrant 2012, 9, 181-208. [CrossRef]

24. Jaskoski, M. Environmental Licensing and Conflict in Peru's Mining Sector: A Path-Dependent Analysis. World Dev. 2014, 64, 873-883. [CrossRef]

25. Vázquez, L.S.; Espinosa, M.G.; Eguiguren, M.B. Perception of socio-environmental conflicts in mining areas: The case of the Mirador Project in Ecuador. Ambiente Soc. 2016, 19, 23-44. [CrossRef]

26. Takano, C.C.; do Flores, J.C.C.; de Lima, H.M. An Analysis of the Rate for Controlling, Monitoring and Supervision of Exploration and Mining Activities of Mineral Resources (TFRM). Rev. Esc. De Minas 2016, 69, 105-110. [CrossRef]

27. Brasil, L.M.; Pires, V. O que a lama nos deixou: Reflexões sobre a tragédia de Mariana, a mídia e a mineração no Brasil. Chron. Des Amériques 2017, 17, 1-10.

28. Singh, J.T.N. Reconstituting the Neostructuralist State: The political economy of continuity and change in Chilean mining policy. Third World Q. 2010, 31, 1413-1433. [CrossRef]

29. Tiess, G.; Ruban, D.A. Geological heritage and mining legislation: A brief conceptual assessment of the principal legal acts of selected EU countries. Proc. Geol. Assoc. 2013, 124, 411-416. [CrossRef]

30. Ubaque, C.A.G.; Vaca, M.C.G.; Rodrígues, C.F. Agudelo. Evaluación y diagnóstico de passivos ambientales mineros en la Cantera Villa Gloria en la localidad de Ciudad Bolívar, Bogotá D.C. Tecnura 2014, 18, 90-102. [CrossRef] 
31. Brasil Superior Tribunal de Justiça. Agravo Regimental no Recurso Especial No 1.394.171—RS (2013/0266001-0). Relator: Ministro Felix Ficher. Brasília (DF), 23 de agosto de 2018. 2018; Special Appeal. Environmental Crime. Exploration of Mineral Resources without Legal Authorization of the National Department of Mineral Production. Principle of Insignificance. No Incidence. Application of the Decriminalizing Standard Provided for in the Sole Paragraph of art. 2nd of Decree-Law n. 227/67. No Incidence. Unauthorized Extraction of Mineral Substances and Immediate Application in the Execution of Public Work Performed by Particular. Available online: https: / / ww2.stj.jus.br/processo/revista/documento/mediado/?Componente=ATC\& sequencial $=86987726 \&$ num_registro $=201302660010 \&$ data $=20180831 \&$ tipo $=5 \&$ formato=PDF $($ accessed on 9 November 2020 ).

32. Passos, F.L.; Coelho, P.; Dias, A. (Des)territórios da Mineração: Planejamento Territorial a Partir do Rompimento em Mariana, MG. Cad. Metrop. 2017, 19, 269-297. [CrossRef]

33. Brasil Agência Nacional de Mineração (ANM). DNPM—Portal de Outorga. 2018. Available online: http:/ / outorga.dnpm.gov.br/ SitePages/Explora\%C3\%A7\%C3\%A30\%20Mineral.aspx (accessed on 29 October 2020).

34. Brasil Ministério do Meio Ambiente. IBAMA-Manual de Normas e Procedimentos para Licenciamento Ambiental no Setor de Extração Mineral. 2001; Brasília. Available online: http:/ /www.mma.gov.br/estruturas/sqa_pnla/_arquivos/MANUAL_ mineracao.pdf (accessed on 8 November 2020).

35. Brasil Superior Tribunal de Justiça. Mandado de Segurança MS 6768 DF 2000/0002376-0. Relator: Ministro José Delgado. Brasília (DF), 26 de outubro de 2000. 2000; “Administrative. Writ of Mandamus. Suspension and Extension of Research Permit Terms. Mining Rights. Concrete and Proven Impediments of the Miner to Enter the Area to Be Explored. Schedule of the Permit Terms Deadline which must Be Assured from the Miner's Effective Entrance into The Area Objected by the Research. Litisconsorcial Assistance Request Formulated by the Company Porto Feliz Ltda. Failure to Complete the Assumptions Elected in Art. 54, of the CPC (Code of Civil Procedure). Inadmissibility". Available online: https:/ / ww2.stj.jus.br/processo/revista/documento/ mediado $/$ ?componente=IMGD\&sequencial=265845\&num_registro=200000023760\&data=20001218\&formato=PDF $($ accessed on 11 November 2020).

36. Bezerra, F.A.S.L. A indenização ao superficiário da mina pelo espaço impactado na pesquisa mineral. Âmbito Jurídico 2013, 16, $1-5$.

37. Brasil Superior Tribunal de Justiça. Agravo em Recurso Especial No 1.205.612—SC (2017/0288229-5). Relator: Ministra Nancy Andrigui. Brasília (DF), 12 de dezembro de 2017. 2017; “Civil Processual. Special Appeal. Action of Accountability. Ineptitude. Declaration Embargo. Omission, Contradiction or Darkness. No Occurrence. Violation of Art. 489, ii, of cpc/15 (art. 458, ii, of cpc/73). Nonoccurrence. Pre-Questioning. Absence. Summary 211/scj. Principle of the Judgment not Disputed. Summary 283/stf. Facts Review. Interpretation of Contractual Clauses. Inadmissibility". Available online: https://ww2.stj.jus.br/processo/revista/ documento $/$ mediado $/$ ? Componente $=M O N \&$ sequencial $=79296927 \&$ num_registro $=201702882295 \&$ data $=20180205 \&$ tipo $=0$ (accessed on 8 November 2020).

38. Brasil Superior Tribunal de Justiça. Embargos de Declaração no Agravo em Recurso Especial No 1.124.158-MG (2017/0150730-8). Relator: Ministro Moura Ribeiro (DF), 01 de Agosto de 2018. 2018; “Embargos of Declaration in the Special Appeal. Civil Processual. Resource Managed under the Aid of the NCPC (New Code of Civil Procedure). Art. 1,022 of NCPC. Omission, Darkness, Contradiction, or Material Error. No Existence. Pretension of Judgment the Cause Again. Impossibility. Decision Maintained. Embargos Rejected with Penalty Application". Available online: https://ww2.stj.jus.br/processo/revista/documento/mediado/ $?$ componente $=$ MON\&sequencial $=85647740 \&$ num_registro $=201701507308 \&$ data $=20180806 \&$ tipo $=0$ (accessed on 12 November 2020).

39. Aragão, V.C. Jurisdição Voluntária. Âmbito Jurídico 2009, 12, 1-4.

40. Couttenier, M.; Sangnier, M. Living in the Garden of Eden: Mineral resources and preferences for redistribution. J. Comp. Econ. 2015, 43, 243-256. [CrossRef]

41. Souza, K.V.; da Villa Verde, R.B.R.; De Alamino, R.C.J.; Fernandes, F.R.C. Mineração na Região Nordeste do Brasil: Quadro atual e perspectivas. In Recursos Minerais e Comunidades: Impactos Humanos, Socioambientais e Econômicos; Fernandes, F.R.C., de Alamino, R.C.J., Araujo, E.R., Eds.; Cetem/Mcti: Rio de Janeiro, Brazil, 2014; pp. 117-123.

42. Brasil Conselho Nacional do Meio Ambiente (CONAMA). Resolução 237, de 19 de dezembro de 1997. 1997. Available online: http:/ / www.mma.gov.br/port/conama/res/res97/res23797.html (accessed on 26 October 2020).

43. Brasil. Decreto-Lei 6.938, de 31 de agosto de 1981. Dispõe sobre a Política Nacional do Meio Ambiente, seus fins e mecanismos de formulação e aplicação, e dá outras providências. 1981; Brasília. Available online: http://www.planalto.gov.br/ccivil_03 /LEIS/L6938.htm (accessed on 21 October 2020).

44. de Rodrigues, G.S.S.C. A análise interdisciplinar de processos de licenciamento ambiental no estado de Minas Gerais: Conflitos entre velhos e novos paradigmas. Rev. Soc. E Nat. 2010, 22, 267-282. [CrossRef]

45. Brasil Superior Tribunal de Justiça. Recurso Especial No 1.374.284-MG (2012/0108265-7). Relator: Ministro Luis Felipe Salomão. Brasília (DF), 27 de agosto de 2014. 2014; “Civil Responsibility for Environmental Damage. Special Appeal Representative of Controversy. Art. 543-c of the CPC. Damage Arising from the Dam Break. Environmental Accident Occurred in January 2007, in the Municipalities of Miraí and Muriaé, State of Minas Gerais. Integral Risk Theory. Causality Nexus". Available online: https: / ww2.stj.jus.br/processo/revista /documento/mediado/?componente=ATC\&sequencial=38502232 \&num_registro=201201082657\&data=20140905\&tipo=5\&formato=PDF (accessed on 13 November 2020).

46. Josa, R.; Jorba, M.; Vallejo, V.R. Opencast mine restoration in a Mediterranean semi-arid environment: Failure of some common practices. Ecol. Eng. 2012, 42, 183-191. [CrossRef] 
47. Lima, A.T.; Mitchell, K.; O'connell, D.W.; Verhoeven, J.; Van Cappellen, P. The legacy of surface mining: Remediation, restoration, reclamation and rehabilitation. Environmental. Sci. Policy 2016, 66, 227-233. [CrossRef]

48. Brasil. Superior Tribunal de Justiça. Agravo Regimental no Recurso Especial No 1.369.723-MG (2013/0048546-5). Relator: Ministro Sidnei Beneti. Brasília (DF), 14 de maio de 2013. 2013; "Regional Damage on Special Appeal. Action of Mining Administrative Easement Institution. Emission in Possession. Offense to arts. 458 and 535 of the CPC. Violation to the Contradictory. New Fact. Deletion of Instance. Summits 282, 283, 356/stf, 7, 211/scj. Improvement". Available online: https:/ /ww2.stj.jus.br/processo/revista/documento/mediado/?componente=ATC\&sequencial=28637619\&num_registro= $201300485465 \&$ data=20130604\&tipo=5\&formato=PDF (accessed on 14 November 2020).

49. Brasil Conselho Nacional do Meio Ambiente (CONAMA). Resolução 9/87, de 03 de Dezembro de 1987. Dispõe Sobre a Realização de Audiências Públicas no Processo de Licenciamento Ambiental. 1987. Available online: http://www.mma.gov.br/port/ conama/legiabre.cfm?codlegi=60 (accessed on 15 November 2020).

50. Brasil Superior Tribunal de Justiça. Agravo Regimental no Recurso Especial No 1.479.063—RS (2014/0223436-1). Relator: Ministra Isabel Gallotti. Brasília (DF), 21 de Novembro de 2017. 2017; “Civil. Mining Law. Damage Repair Action c/c Obligation to Do Art. 466-a of the Civil Procedure Code. Wrong Disclaimer of Clandestine Mining. Configured Illicit Act. Mining Extraction Stopped. Lost Profits. Subject Matter. Review. Inadmissibility. Summary 7/scj. Resource Known and not Provided". Available online: https: / / ww2.stj.jus.br/processo/revista /documento / mediado / ?componente=ATC\&sequencial=78633177 \&num_registro=201402234361\&data=20171129\&tipo=41\&formato=PDF (accessed on 12 November 2020).

51. Voulvoulis, N.; Skolout, J.W.F.; Oates, C.J.; Plant, J.A. From chemical risk assessment to environmental resources management: The challenge for mining. Environ. Sci. Pollut. Res. 2013, 20, 7815-7826. [CrossRef] 